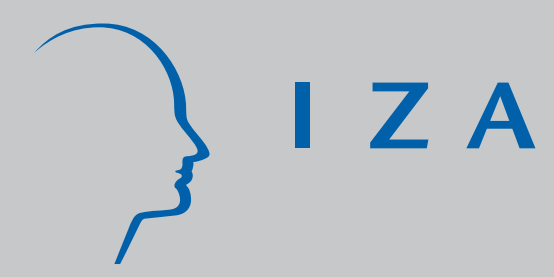

IZA DP No. 169

Immigration Policies and their Impact:

The Case of New Zealand and Australia

Rainer Winkelmann

July 2000 


\title{
Immigration Policies and their Impact: The Case of New Zealand and Australia
}

\author{
Rainer Winkelmann \\ IZA, Bonn \\ Discussion Paper No. 169 \\ July 2000 \\ IZA \\ P.O. Box 7240 \\ D-53072 Bonn \\ Germany \\ Tel.: +49-228-3894-0 \\ Fax: +49-228-3894-210 \\ Email: iza@iza.org
}

This Discussion Paper is issued within the framework of IZA's research area Mobility and Flexibility of Labor Markets. Any opinions expressed here are those of the author(s) and not those of the institute. Research disseminated by IZA may include views on policy, but the institute itself takes no institutional policy positions.

The Institute for the Study of Labor (IZA) in Bonn is a local and virtual international research center and a place of communication between science, politics and business. IZA is an independent, nonprofit limited liability company (Gesellschaft mit beschränkter Haftung) supported by the Deutsche Post AG. The center is associated with the University of Bonn and offers a stimulating research environment through its research networks, research support, and visitors and doctoral programs. IZA engages in (i) original and internationally competitive research in all fields of labor economics, (ii) development of policy concepts, and (iii) dissemination of research results and concepts to the interested public. The current research program deals with (1) mobility and flexibility of labor markets, (2) internationalization of labor markets and European integration, (3) the welfare state and labor markets, (4) labor markets in transition, (5) the future of work, (6) project evaluation and (7) general labor economics.

IZA Discussion Papers often represent preliminary work and are circulated to encourage discussion. Citation of such a paper should account for its provisional character. 
IZA Discussion Paper No. 169

July 2000

\section{ABSTRACT \\ Immigration Policies and their Impact: The Case of New Zealand and Australia*}

The paper provides an analysis of the recent immigration history of New Zealand and Australia. It starts with a description of the quantitative dimension of immigration: how many immigrants entered the two countries, and what was the contribution of external migration to population growth. Next, similarities and differences in the current immigration policies are studied. Finally, an attempt is made to evaluate policy outcomes using empirical evidence of immigrants arriving in the 1990s.

JEL Classification: J61, J68

Keywords: Point system, skilled immigration, population growth

Rainer Winkelmann

IZA

P.O. Box 7240

D-53072 Bonn

Germany

Tel.: +492283894122

Fax: +492283894210

Email: winkelmann@iza.org

*I thank Slobodan Djajic and Jacques Poot for valuable comments on an earlier draft, and Sibel Duman for her research assistance. 


\section{Immigration in New Zealand and Australia: A quantitative view}

In this part, we will assess the status of Australia and New Zealand as immigration countries in the last decade(s) of the $20^{\text {th }}$ century. ${ }^{1}$ Both New Zealand and Australia remain relatively unpopulated countries, and hence offer ample opportunity for population growth. ${ }^{2}$ How were these opportunities perceived and dealt with, and what were the results that followed? An early report of the then just founded Australian Department of Immigration defined in 1945 that Australia's need for a greater population for the purposes of defence and development would be served well by a population growth rate of two percent per annum, one percent from natural increase and one percent from immigration (Price, 1998). Towards the end of the 1990s, New Zealand's government set the target for the annual number of residence approvals at 35,000 , again about one percent of the population, although based more on a judgement of the society's absorptive capacities rather than on an overall population goal. Thus, it appears that this "one percent" immigration rule is a useful point of reference against which the empirical evidence can be gauged.

A possible metric for assessing the openness of a country and the effects of international movements of people on its population size is net permanent and long-term (PLT) migration. As island states, both Australia and New Zealand can keep relatively reliable records of border movements through arrival and departure cards. While some details of the system differ in the two countries, the general idea is to ask people arriving (leaving) about their intended duration of stay in the country of arrival (or the country they departed for). Responses of 12 months or longer (but not permanent) are classified as "long-term" migration. Apart from some other socio-demographic characteristics, these cards also contain information on country of birth, country of citizenship, and on residence status in the local country. 
Table 1 provides information on population sizes and net-PLT migration for New Zealand and Australia between 1979 and 1996. New Zealand's population grew by 16 percent (or 0.8 percent per year) from 3.1 million to 3.6 million. Australia's population grew by 26 percent (or 1.3 percent per year) from 14.5 million to 18.3 million. Hence, both countries fell short of the overall 2 percent yardstick (for natural increase plus net-migration), but the discrepancy was particularly large for New Zealand. The main culprit was its negative cumulative net-PLT migration, i.e., more people left New Zealand long-term or permanently than arrived. Australia by contrast gained 1.6 million people through external migration, 43 percent of the overall increase in population. However, even Australia's net-PLT migration never reached the aforementioned 1 percent of the population, with an average net-migration rate of 0.59 percent.

\section{Table 1 about here}

Despite the finding of negative net-migration for New Zealand over most of the period, ${ }^{3} \mathrm{New}$ Zealand was an immigration country as well as an emigration country. This apparent contradiction is resolved when New Zealand nationals are considered separately from nonnationals. The third column of Table 1 gives the net-PLT migration statistics for non-NZ nationals only. It is found that non-NZ PLT migration generated a substantial surplus of 240,000 people between 1979 and 1996, 48 percent of the total population growth over the period. Moreover, the trend in non-NZ PLT migration is upward, reaching more than 1 percent of the population in 1996. In the early and mid-1990s, New Zealand's immigration program was substantially larger than Australia's in relative terms. However, the substantial inflow of immigrants was more than offset by international movements of New Zealand nationals who generated a combined deficit of 342,000 between 1979 and 1996 . While there 
was a net loss of NZ nationals in every year, the magnitude was quite volatile, ranging from almost 40,000 in 1979 to less than 2,000 in 1984.

Most outmigrating New Zealand nationals leave for Australia. The Trans-Tasman Travel Agreement gives full freedom of movement, i.e., nationals can live and work anywhere in the two countries without a requirement of residence or work permits. As a rule of thumb, one in ten New Zealanders can be found in Australia. ${ }^{4}$ Of course, many migrants return, and "permanent migration" is difficult to define in this context. However, of the estimated 404,750 New Zealand nationals who were present in Australia at 30 June 1999, slightly more than half had been there for more than 12 months (DIMA, 2000). ${ }^{5}$ In principle, the TransTasman Travel Agreement would also allow Australians to settle in New Zealand. But this option is taken up much less frequently, and only 54,708 Australia-born people were enumerated in the 1996 New Zealand Census. Hence, Trans-Tasman migration is to a large extent a "one-way street".

Of course, the emigration decisions of a country's nationals are not (at least not directly) subject to government policy. By contrast immigration policy directly affects the inflow of non-nationals, whereas settlement policy is one of the determinants of outflow of nonnationals. Hence, one could focus on the gross or net inflow of non-nationals as an indicator of the stance of immigration and settlement policy, rather than on overall net migration. By this measure, the gap between New Zealand and Australia is reduced indeed. The net-inflow of immigrants, as defined by net-PLT migration, was on average 0.38 percent of the population in New Zealand. In the period 1991-1996, the average net migration rate of nonnationals was 0.68 percent for New Zealand, much higher than the overall net migration rate of 0.39 percent for Australia. 
The long-term importance of immigration for Australia and New Zealand can be assessed also by analysing the composition of the population at one point in time. Common measures used in this context are the composition of the population by place of birth (i.e. foreign- or overseas- born versus native), the composition including second-generation immigrants, or, more generally, the ethnic composition. These are long-term measures, since depending on mortality, age-at-arrival and the population increase of the native population, the proportion of migrants is affected by the cumulative immigrant flows over the last half century and longer, and there is no simple link between the more recent flows and the overall stock of migrants.

The proportion of foreign-born residents is substantial in both countries: 17.6 percent of New Zealand residents were foreign born in the last available census of 1996 (Cook, 1997). 23.3 percent of the Australian population were foreign born as of 30 June $1997 .{ }^{6}$ This gives Australia the lead among the traditional immigration countries. For instance, 17.4 of the Canadian population was born overseas in 1996, and 9.3 percent of the U.S. population. The gap between the proportion of foreign-born New Zealand residents and foreign-born Australian residents mainly reflects historically higher net-migration gains in Australia, that built up since World War II. At current immigration rates, the share will stabilise or decline in Australia, but further increase in New Zealand as both the departure of New Zealand-born people and the arrival of overseas settlers push up the proportion of foreign-born. For instance, between 1986 and 1996, i.e. in just ten years, the proportion of foreign born among New Zealand residents increased by more than two percentage points from 15.4 to 17.5 (Winkelmann and Winkelmann, 1998a). 


\section{Immigration in New Zealand and Australia: A qualitative view}

In any classical immigration country, a distinction can be made between economic and social migrants. The social stream has again two components, one being family reunification, the other humanitarian. While the humanitarian program tends to be the smallest among the three in Australia and New Zealand (this program includes an annual UNHRC refugee allocations of 4,000 to Australia and 800 to New Zealand, but the total size usually is two or three times as large), family reunification is a major factor, even though various steps have been undertaken over the years to limit the size of this stream.

The emphasis of the further analysis will be on Australia's and New Zealand's policy rules for the selection of economic migrants. Only this category provides the immediate possibility to select migrants based on personal characteristics and thus to exert a direct influence on "quality" aspects of migration. For New Zealand and Australia, two themes stand out behind the policy changes of the last half-century. The first is the abolition of ethnic background considerations; and the second is the shift from an "occupational needs principle" towards a "general skills principle", reflecting a change in the perception of the economic benefits of the types of skills that are involved.

\section{1 Occupational migration}

Traditionally, successive New Zealand and Australia Governments from the 1950s and 1960s onwards regarded economic immigration as an instrument of labour market policy, to be applied to alleviate skill shortages in particular sectors, rather than as a force for broader economic growth. The mechanism used to control entry on this basis was an "Occupational 
Priority List". Employers wanting to recruit persons for occupations not on the list had to demonstrate that no suitable local resident was available or readily trained. In the 1990 s the two countries' policies on this issue started to diverge. While New Zealand completely abandoned occupational targeting in 1991, Australia weakened its importance but nevertheless kept various direct and indirect instruments of occupational selection in place. For instance, preference is given in general to migrants in occupations that are part of a socalled "Migration Occupations in Demand List (MODL)". Moreover, the economic migration program continues to include a so called Employer Nomination Scheme for skilled persons nominated for a specific skilled position by an Australian employer who has not been able to fill a vacancy from the local labour market or by training.

\subsection{Cultural Diversity}

The second important characteristic of immigration policy is its ethnic dimension. The colonial past shaped immigration policy in both countries well into the second part of this century. For instance, in New Zealand, Commonwealth citizens of European ancestry and Irish citizens had unrestricted right of entry for residence until 1974. A complete break with an ethnic preference system did not occur until 1987 in New Zealand, when a "nondiscriminatory" immigration policy was officially adopted. Prior to 1987, workers from socalled "Traditional Source Countries" were given priority in filling positions on the occupational priority list. To recruit from a non-traditional migrant source country an employer had to show they could not recruit either in New Zealand or from a traditional source country and that the skills were not in demand in the country of origin (NZIS, 1997). This was a substantial constraint on occupational entry from non-traditional countries. 
Traditional source countries were those from which New Zealand had previously taken substantial numbers of immigrants and/or which had vocational training schemes similar to its own. Initially, this list included most countries from Western and Northern Europe, plus Italy, the United States and of course the United Kingdom. This was effectively a "white New Zealand" policy, although it was not called that way at the time. In the mid 1970s, however, the list of countries was extended, opening up the possibility for large-scale immigration for Pacific Islanders. Pacific Island immigration was also given a boost by a general amnesty in 1976 for a large number of de-facto immigrants who had come to New Zealand with temporary work permits and were given permanent residence status. Pacific Island immigration remained important throughout the 1980s.

A review of New Zealand's immigration policy was conducted in 1986. Factors motivating this review included a desire to explicitly acknowledge New Zealand's location in the AsiaPacific region (considering that immigration from within this region might foster trade, attract investment, and increase cultural diversity), and a desire to tidy up some of the administrative and legal shortcomings of the old legislation (Burke, 1986). The resulting Immigration Act 1987 abolished the "traditional source" preference list. It maintained the system of an occupational priority list until it was finally abandoned in 1991.

Australia was notably faster in formally giving up its "White Australia" policy of immigration. The gradual process took place over a period of 25 years and came to a conclusion as early as 1966 when Immigration Minister Opperman, after a review of the nonEuropean immigration policy, announced applications for migration would be accepted from well-qualified people on the basis of their suitability as settlers, their ability to integrate readily and their possession of qualifications deemed useful to Australia. 
A the same time, the Government decided that a number of non-Europeans, who had been initially admitted as "temporary" residents, but who were not to be required to leave Australia, could become residents and citizens after five years (i.e. the same as for Europeans), instead of 15 years previously required. These policy changes triggered a period of steady expansion of non-European migration, and the non-discriminatory immigration policy was reconfirmed and strengthened by various policy reviews in 1973 and 1978, among others.

The cumulative quantitative effects of these policies are visible in Table 2, which shows the distribution of the foreign-born population by region of birth for the two countries in 1995/1996. In both Australia and New Zealand, UK and Ireland constituted the most important countries of origin. However, the dominance was much less pronounced in Australia, where other European countries were more represented and, when combined, almost reached the share of UK and Ireland. This reflects the fact that at various times in the 1950s and 1960s, the Netherlands, Germany, Italy, Greece, Turkey and Yugoslavia were important migrant source countries for Australia. For New Zealand, however, the only substantial non-UK inflow from Europe was a Dutch migration wave in the 1950s.

\section{Table 2 about here}

Moreover, Australia in 1995 had a much larger share of immigrants from the Middle East and North Africa, as well as South and Central America than New Zealand. On the other hand, a disproportionate number of New Zealand's immigrants came from Oceania, i.e., mainly the Pacific Islands. The share of Asian immigrants was about the same in the two countries, one in five. Overall, though, one can clearly uncover the earlier commitment of Australia to a policy of diversified immigration. Apart from Asian and Pacific Island immigration, New 
Zealand drew immigrants mainly from two countries, the UK and the Netherlands, whereas Australia attracted migrants from a much wider pool of countries.

\subsection{Current Policy}

At first glance, current immigration policies in Australia and New Zealand are very similar. The similarity starts with the official policy objectives. For New Zealand, official statements define goals such as "to allow entry to migrants who would make the highest contribution to employment and income growth" and "to maximise the gain in productive human capital while maintaining provisions for migrants to enter New Zealand for social and humanitarian reasons" (NZIS 1997). Similarly, for Australia, one finds quotes that immigration should deliver an intake that "has broad-based skills with the capacity to contribute to Australia's economy" (DIMA, 2000).

In both cases, economic migration is deemed to bring into the country "productive human capital" or "broad based skills". The motive of short-term fixes for occupational labour market imbalances has been replaced by a longer-term perspective that fits into the current emphasis on a "knowledge society". In fact, Australia advertises its multicultural society as a competitive advantage: “'Productive Diversity' is an expression which recognises the economic value of Australia's culturally diverse society. Through 'Productive Diversity', companies can develop a competitive advantage by leveraging their most valuable resource: their people.” (DIMA, 2000, Fact Sheet 12).

Further similarities concern the general structure of the immigration program, with its division into economic, family and humanitarian migration. And finally, the economic program in both countries is implemented as a point system. Points are allocated for employability, age and 
settlement factors, and an adjustable pass mark is set in order to meet a given target number of successful applications. In Australia's case, the target is an upper limit, whereas New Zealand operates a soft target that can be exceeded in single years. 


\subsection{The point system}

Points are awarded in a way that is thought to promote a selection of "the most productive" applicants. From the perspective of human capital theory, the task is to determine the value of the transferable human capital a person is endowed with (or, more precisely, the present value of the stream of income associated with that human capital). Not surprisingly, then, the factors entering the point system are similar to those one would find in a typical Mincerian earnings function, augmented by life-cycle considerations: e.g. the level of schooling, actual labor market experience, language proficiency, and age. The points awarded to each characteristic could be seen as an assessment of the returns to these productive characteristics (in terms of higher life-time productivity/income) in the host country labor market.

Table 3 gives the current structure of the point system for skilled migrants in the two countries. ${ }^{7}$ The guiding principles of the human capital model can be identified in both systems, although it is more purely presented in New Zealand. The current New Zealand pass mark is set at 25 points. A maximum of 12 points can be obtained for formal qualifications (Master degree or higher), a maximum of 10 points for experience (one point for each two years), and a maximum of 10 points for age (25-29 years). An offer of employment brings 5 points, and a variety of other settlement factors can bring a maximum of 7 additional points.

\section{Table 3 about here}

There is a trade-off between age at the time of application and labor market experience that can be illustrated with some simple calculations. Assume that an applicant had an uninterrupted working career. In this case someone who started to work at the age of 18 obtains a maximum of 16 points for age and experience if aged 29-39 at the time of the 
application. For a starting age of 20 years, 16 points are reached for those aged 39 on application. If the applicant started to work at the age of 25 , the maximum achievable number of points is 14 when aged 44. Despite the step-wise nature of the system, a general pattern emerges: In general, it is better to have started the working career at an early age. The optimal migration age is an increasing function of age at entry into the labour market. Interestingly, the inclusion of points for experience leads to a system where immigrants tend to be older (the prime-age range is between 29 and 44), and one can question whether the system sufficiently appreciates the common research finding that younger immigrants tend to be more easily integrated into the host country labor market than older immigrants.

The pattern is complicated, though not overturned, by including also qualifications, as qualifications and experience, for a given age, are negatively related. It is interesting to note that a minimum base qualification is not necessary to get over the pass mark if an offer of employment and other settlement factors exist. However, if settlement factors do not apply, then both a qualification and, in most cases, an offer of employment will be necessary to gain entry into New Zealand. The "returns" to a qualification beyond the base qualification are not very high (or even negative, if other factors are taken into account). In general, a Ph.D. is worse off than a Bachelor's degree because the years spent as a student do not qualify for work experience.

Finally, it is of importance how the language requirement is implemented. This was, and remains, one of the more contentious areas of the system, as reflected in the fact that rules were changed substantially on two occasions since the introduction of the point system in 1991. Initially, the English language requirement affected the principal applicant only. In contrast to Australia, no points were awarded but a certain level of proficiency was a nonnegotiable requirement. In October 1995, the English language requirement was extended 
from just the principal applicant to all adult family members. A bond had to be paid per nonspeaker to the government. The bond was refunded if sufficient English skills were acquired within a certain period of residence. A further change in 1999 replaced the bond-system by the requirement to pre-purchase English language training in New Zealand. Australia operates de-facto a similar system: although migrants are entitled to 510 hours of government-funded tuition (or the number of hours it takes to reach functional English), adults with insufficient English proficiency are liable for a so-called $2^{\text {nd }}$ Instalment payment upon arrival (that tends to be somewhat below the pre-purchase amount required in New Zealand).

The Australian system features a current pass mark of 110 points. Qualifications are not rewarded per-se, but rather in relation to occupations they lead into. Up to 60 points can be obtained here. No special mention is made of high-level academic training. A Ph.D. is not rewarded, unless it comes from an Australian university (which, of course, is a good way to "sell" Australian education programs in the Asian market). ${ }^{8}$ Points for experience are awarded if the person worked in a skilled occupation for at least three out of the last four years. This ruling tends to favour younger immigrants (relative to the New Zealand system). This effect is reinforced by the maximum age, which is set at 45 years for Australia but at 55 years for New Zealand. It was already mentioned before that occupation plays still an active role in the Australian selection process, whereas it doesn't in New Zealand. Australia operates a "Migration Occupation in Demand List", and five extra points are awarded for occupations on that list, ten extra points if employment for such an occupation has been offered. Finally, English proficiency is part of the point system in Australia. This has two consequences. First, non-proficient principal applicants are not a-priori excluded from consideration. And second, it becomes possible to distinguish between levels of proficiency, as "very proficient" speakers (competent English) are awarded five more points over "proficient" speakers (vocational English). 
In summary, although both countries operate a point system to select skilled economic migrants, the relative valuation of potential migrant's characteristics is not the same. The Australian system prefers younger migrants with specific occupational skills. The New Zealand system generally provides less room for differentiation. Most importantly, it does not target specific skills but rather adheres to the "general skills principle". This "hands-off" policy is consistent with the devolution and reduction of government influence that came to be associated with the New Zealand reform agenda starting in 1984. While the resulting system has the advantage of simplicity, transparency, and conformity to the prevailing economic paradigm, it is not clear whether it leads to results that are superior to those of the more pragmatic Australian approach with its larger scope for micro-management. Some tentative empirical evidence on selection outcomes is considered next.

\subsection{Outcomes}

A comprehensive assessment on the relative merits of the two selection processes, in comparison with each other, and in comparison with alternative systems as they are operated in other countries, in the sense of a formal evaluation study, is beyond the scope of this survey paper. To the best of my knowledge, such an analysis has not been attempted yet. There are certainly immense conceptual and practical problems to overcome. Availability of appropriate data is one, but it is also unclear what exactly should one measure and compare. A paper that touches on the issue (Cobb-Clark and Connolly, 1997) considers the number of applicants to Australia, by country, and acceptance rates as an indicator of quality. However, Cobb-Clark and Connolly concentrate on the effects of inflows to two other major immigration countries (U.S. and Canada, they ignore New Zealand), rather than on features of the Australian system itself. They come to the rather sobering conclusion that the possibilities for being selective are 
limited: since the pool of qualified internationally mobile migrants is small relative to the overall demand, and since Australia is only a "small player", it must accept most of the applicants, unless the annual intake is to be reduced quiet a bit. If this is a valid argument for Australia, then it must be even more so for the even smaller "player" New Zealand.

Of course, for the direct competition between Australia and New Zealand, differences in the details of the migration system may still be decisive. To shed some light on this question, the modest goal of this section is threefold. First, the proportion of skilled migrants among all migrants is analysed, indicating potential differences in the "bite" of the selection process with regard to the quality of the average migrant. Second, differences in the country of origin composition of successful applicants are studied. Third, unemployment rates of recent immigrants are compared.

Prior to presenting the evidence, one should ask, however, whether from a prospective migrants point of view, the two countries can be considered as good substitutes. In other words, are the two countries likely to draw from the same pool of applicants? The standard model of migrant's choice emphasizes the relative returns to skills in the two countries, and thus inequality, as one factor. But absolute income levels matter as well. And while inequality measures are not so different in Australia and New Zealand (Deininger and Squire, 1996), absolute income measures increasingly are. For example, between 1949 and 1998, per capita GDP increased on average by 2.1 percent per annum in Australia, compared to 1.4 percent in New Zealand (Dalziel, 1999).

Concurrently with the increasing per capita GDP gap, considerable salary differentials have developed between New Zealand and Australia. The difference in growth of economic activity and opportunity not only provides a partial explanation to the observed one-way 
Trans-Tasman traffic of young New Zealanders to Australia, but it also is likely to mean that New Zealand is only second choice for many prospective migrants. It also means that job opportunities for skilled workers tend to be more limited in New Zealand. This should be kept in mind in the following analysis.

One measure of the potential effects of the point systems for skilled migration on the overall immigrant quality is the proportion of points-tested migrants among all migrants in a given year, with family and humanitarian migration being the alternatives. Table 4 aggregates these two categories into a single "social"-migration category. It is found for New Zealand that between 1992 and 1998, about one half to two thirds of all migrants were subject to the points test. ${ }^{9}$ In Australia, where family and humanitarian migration is relatively more important, this proportion was significantly lower, ranging from 25 to 50 percent. Efforts have been made in recent years to increase the share of economic migrants, with some success, as can be seen from Table 4.

Table 4 about here.

There is ample research evidence that the country-of-origin composition is one of the main contributing factors to immigrant's labour market success. In particular, in the case of Australia and New Zealand, it is common practice for outcome studies to distinguish between immigrants with English speaking background (ESB) and those with non-English speaking background (NESB) (See, for instance, Miller (1986), Beggs and Chapman (1988), McDonald and Worswick (1999), Winkelmann and Winkelmann (1998)). It is generally found that NESB migrants have labour market outcomes (e.g. earnings, unemployment rates) that are considerably worse than those of ESB migrants. 
Table 5 shows the Top-10 countries of Origin for the economic migrants who obtained their residence permit in the year ending June 1997. In both countries, UK and Ireland are still the most important single source countries. ${ }^{10}$ However, Asian immigration clearly dominates migration from Europe. The combined share of Asian countries in the Top-10 list was 30 percent in New Zealand and 44 percent in Australia. Furthermore, there was substantial migration from South Africa in both countries, reflecting the political changes taking place in that country. Taken together, about one half of the approvals in either country were for migrants with English speaking background, and one half for those without.

Table 5 about here.

A further point worth noting is the continuing difference in the degree of diversity between the two countries. It was already shown in section 3.2., that Australia's immigration history is characterized by greater ethnic and country-of-origin diversity. Table 5 shows that this trend continues into the present. For instance, the Top-3 countries had a combined share of 55 percent of all approvals in the case of New Zealand, but only 39 percent in the case of Australia. One possible explanation can be found in models of "network migration" (for an overview, see Bauer and Zimmermann, 1998) according to which migration may become selfperpetuating because the cost and risks of migration are lowered by social and informational networks that have been built up through previous migrants. Network migration could also explain, why New Zealand continues to be an important receiving country for Pacific Islanders, whereas Pacific Island migration is much less important for Australia.

Table 6 shows the unemployment rates for recent immigrants in Australia and New Zealand. Unemployment is only one among several possible measure of labour market success. It is chosen here for pragmatic reasons, because of the availability of comparable information for 
the two countries. While the focus on recent immigrants provides an incomplete picture of the overall contribution of immigrants to the economy, as it ignores issues of assimilation and integration, it gives a useful yardstick as it reflects the immediate impact of recent selection policies and as it remains relatively unaffected by selective outmigration.

The Australian statistics are provided by Williams, Brooks and Murphy (1997), based on a sample survey of immigrants in 1994 or 1995 . The New Zealand statistics are based on the study by Winkelmann and Winkelmann (1996a) and refer to the 1996 census. Both sources refer to all arrivals and do not distinguish between economic and social immigrants. This puts some limits on the interpretation. Also, when comparing the statistics, one should be aware that the base years are not the same, and that the definition of "recent immigrants" differs somewhat, from 3-6 months after arrival in Australia to 0-11 month after arrival in New Zealand. The latter difference tends to be in favour of New Zealand's immigrants, although the magnitude of this effect is unclear.

\section{Table 6 about here}

The overall unemployment rates of recent immigrants were 35 percent for New Zealand and 39 percent for Australia. At first, these rates look exorbitantly high, as overall unemployment rates were well under 10 percent over the period. However, one has to recognize that unemployment rates for other new labour market entrants are high as well. Williams, Brooks, and Murphy (1997) provide some estimates for Australia. According to these, 27 percent of those who left the education system at the end of 1993 were unemployed five months later. A 1995 survey of Australian first time labour market entrants (those who just finished the education system plus others) estimated their unemployment rate to be 45 percent. 
Table 6 also decomposes the unemployment rates by gender, age and region of origin.

Women have higher unemployment rates in both countries. The differences are not as large as one might expect though, considering that women are often tied movers who are not screened independently as economic migrants. The age-unemployment patterns are opposite in the two countries: u-shaped (with a low between 25-34) in Australia and inverse u-shaped (with a high between 35-54) in New Zealand. The inverse u-shape in New Zealand is unusual, and it contrasts with the pattern in the New Zealand-born population. Finally, as expected, the table reveals substantial region-of-origin effects: unemployment rates are lowest for Europe-born immigrants and highest for Asian-born immigrants. This discrepancy could be an expression of the "English-language" effect, or capture cultural or some other differences.

Overall, one can conclude from the evidence presented in Table 6 that despite some differences between the outcomes of immigrants, none of the two countries stands out as particularly superior. The main impression in fact is one of similarity: immigration is by no means a "painless" process. It is associated with high initial unemployment rates, and European immigrants continue to be better off in the two countries relative to immigrants from other regions.

\section{Summary and Conclusions}

Throughout the 1990s, New Zealand and Australia experienced substantial immigration although its effect on overall population growth was small by historical standards. In New Zealand's case, despite a substantial intake, immigration was only partially able to offset the population loss due to New Zealanders leaving. In Australia's case, the immigrant intake was relatively smaller. But with modest outmigration, it nevertheless generated a steady net migration gain. 
The most significant policy event over the last half-century was the abolition of the "traditional source country" preference with its resulting ethnic diversification. More recently, both countries refined their selection process with regard to economic migrants. The New Zealand approach is human capital based and emphasizes general skills in its selection. The Australian approach has similar elements, although it appears somewhat more pragmatic by maintaining elements of occupational selection.

In both countries, the region-of-origin composition continues its shift from Europe towards Asia. Immigration is associated with high initial unemployment rates, while European immigrants continue to be better off relative to immigrants from other regions in both countries. It is difficult to draw firm conclusions with respect to the effect of policies on outcomes. One potential lesson is that the limited supply of highly skilled, internationally mobile workers puts a binding constraint on a country's ability to implement a skill-based immigration policy. 


\section{REFERENCES}

Bauer, T. and K.F. Zimmermann (1998) Causes of International Migration: A Survey, in: C. Gorter, P. Nijkamp, and J. Poot (eds.) Crossing Borders. Regional and Urban Perspectives on International Migration, Ashgate: Aldershot.

Beggs, J.J. and B.J. Chapman (1988) Immigrant wage adjustment in Australia: cross section and time-series estimates, Economic Record 64, 161-167.

Brosnan, P. and J. Poot (1987) Modelling the determinants of Trans-Tasman migration after World War II, The Economic Record 63, 313-329.

Burke, K. (1986) Review of Immigration Policy, Appendix to the Journals of the House of Representatives 1986-87.

Cobb-Clark, D.A. and M.D. Connolly (1997) The Worlwide Market for Skilled Migrants: Can Australia Compete? International Migration Review 31, 670-693.

Cook, L. 1997 New Zealand's Current and future Population dynamics, Paper presented at the Population Conference held in Wellington on 12-14 November 1997.

Dalziel, P. (1999) New Zealand's economic reforms failed to achieve their ultimate objectives, University of Canterbury, mimeo.

Deininger, K. and L. Squire (1996) A New Data Set Measuring Income Inequality, World Bank Economic Review 10(3), 565-591.

Gorbey, S., D. James, and J. Poot (1999) Population Forecasting with Endogenous Migration: An Application to Trans-Tasman Migration, International Regional Science Review $22,69-101$.

Department of Immigration and Multicultural Affairs (DIMA) (2000), various fact sheets under http://www.immi.gov.au/statistics/migrant.htm

McDonald, J.T. and C. Worswick (1999) The earnings of immigrant men in Australia: assimilation, cohort effects, and macroeconomic conditions, Economic Record 75, 4962.

Miller, P.W. (1986) Immigrant unemployment in the first year of Australian labour market activity, Economic Record 62, 82-87. 
Nana, G. and J. Poot (1996) Trans-Tasman Migration and Closer Economic Relations, in: P.J. Lloyd and P.S. Williams (eds.) International Trade and Migration in the APEC region, Oxford University Press.

New Zealand Immigration Service (NZIS) (1997), New Zealand Immigration Policy and Trends, paper prepared for the Population Conference held in Wellington on 12-14 November 1997.

Poot, J. (1995) Do Borders Matter? A Model of Interregional Migration in Australasia, Australasian Journal of Regional Studies 1, 159-182.

Poot, J., G. Nana and B. Philpott (1988) International migration and the New Zealand economy: A long-run perspective. Wellington: Victoria University Press for the Institute of Policy Studies.

Price, C.A: (1998) Post-war immigration: 1947-98, Journal of the Australian Population Association, 15, 115-129.

Shroff, G. (1988) New Zealand's immigration policy, New Zealand Official Yearbook 198889, 193-207.

Williams, L.S., C. Brooks and J. Murphy (1997) The initial labour market outcomes of immigrants, Australian Bulletin of Labour 23, 193-213.

Winkelmann, L. and R. Winkelmann (1998a) Immigrants in the New Zealand labour market: A study of their labour market outcomes, Wellington: New Zealand Department of Labour.

Winkelmann, L. and R. Winkelmann (1998b) Immigrants in the New Zealand Labour Market: a Cohort Analysis using 1981, 1986 and 1996 Census Data, Labour Market Bulletin 1998:1\&2, 34-70.

Winkelmann, R. (2000) The Labour Market Performance of European Immigrants in New Zealand in the 1980s and 1990s, International Migration Review, Vol.34 (1), 33-58. 


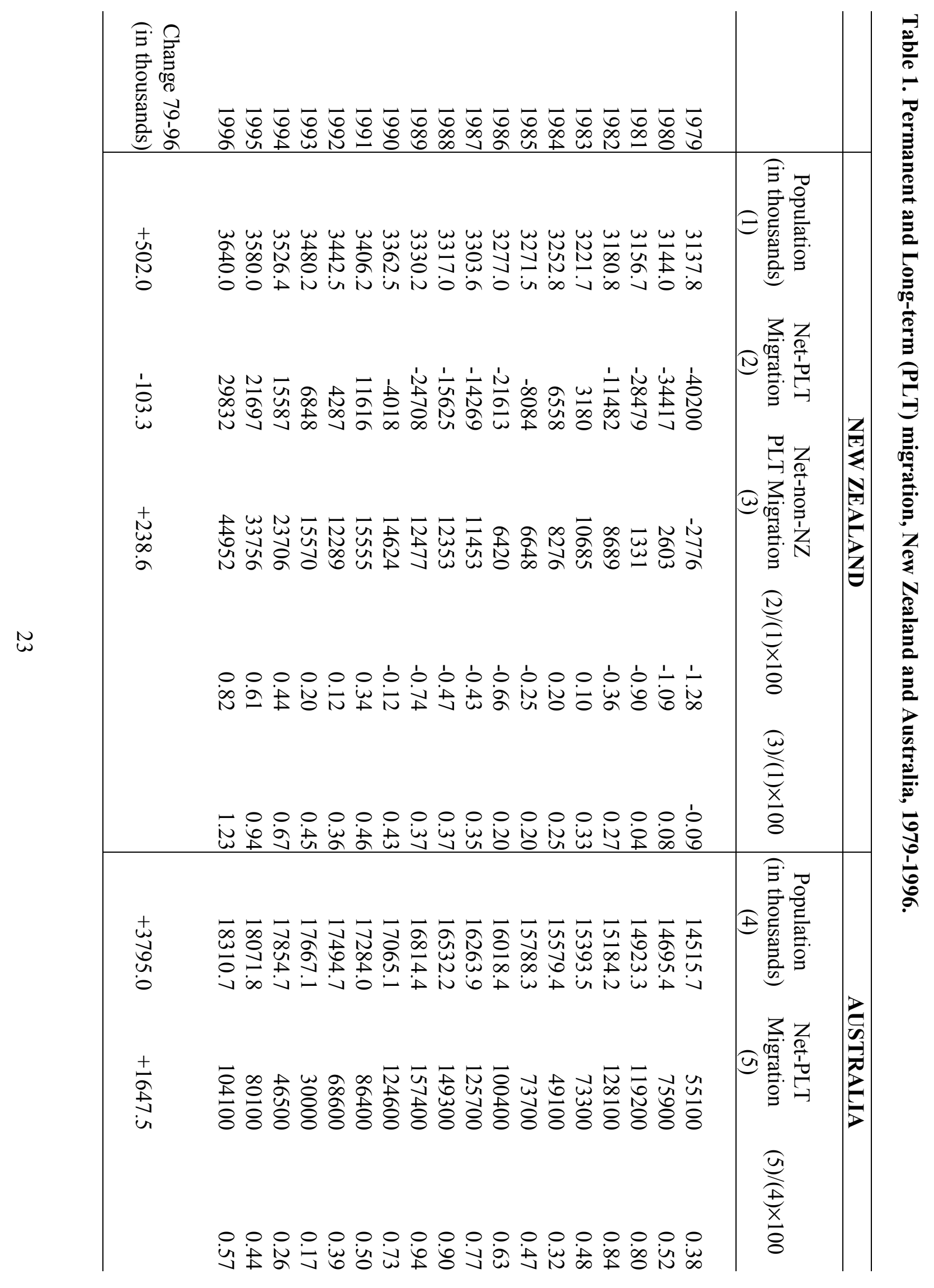




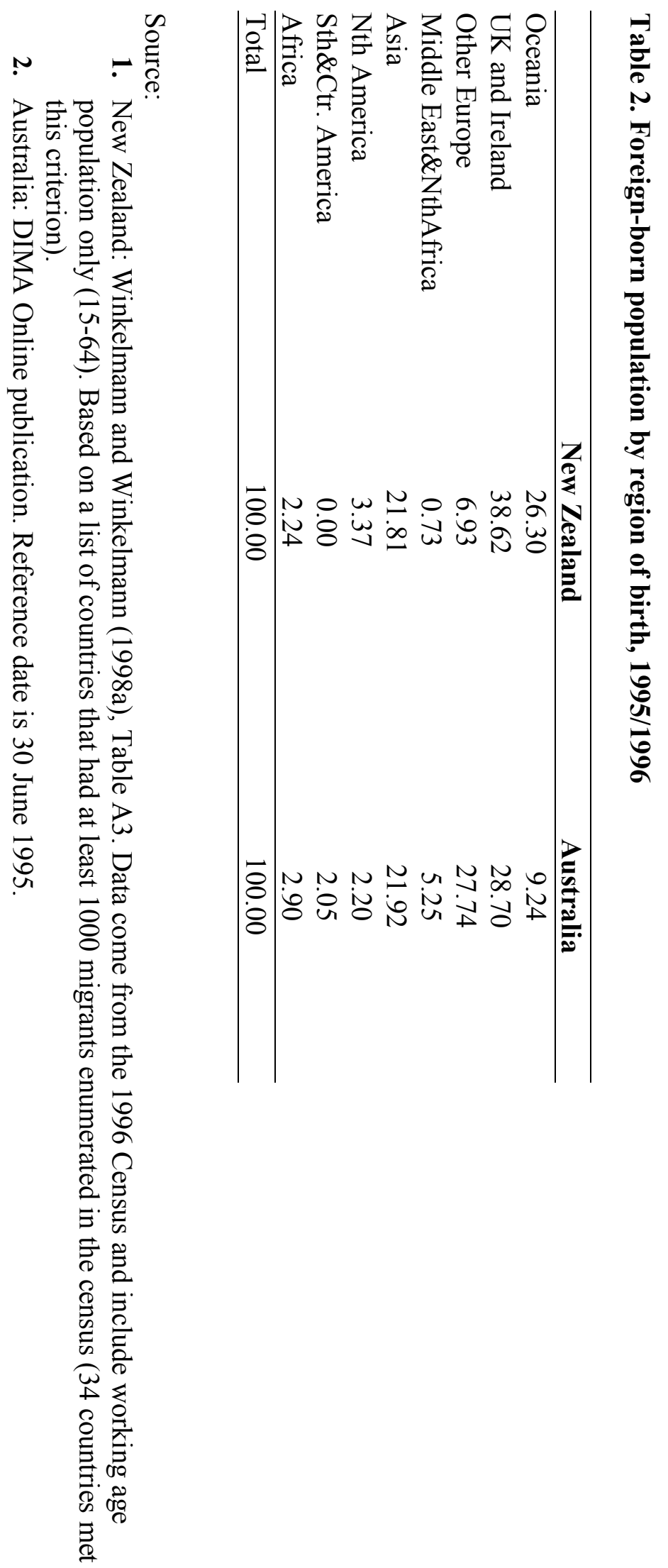



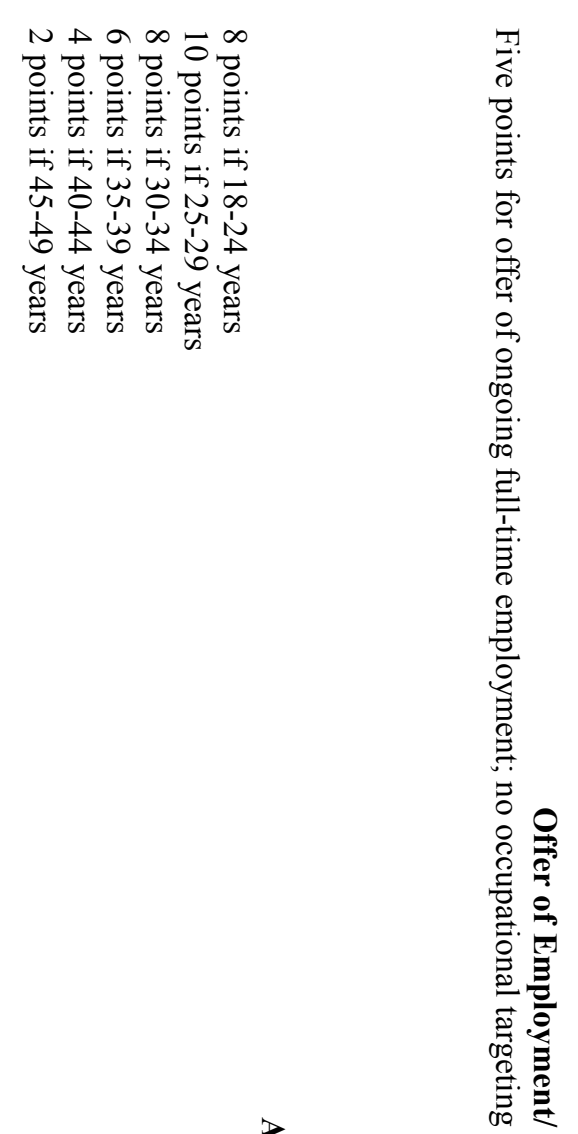

N
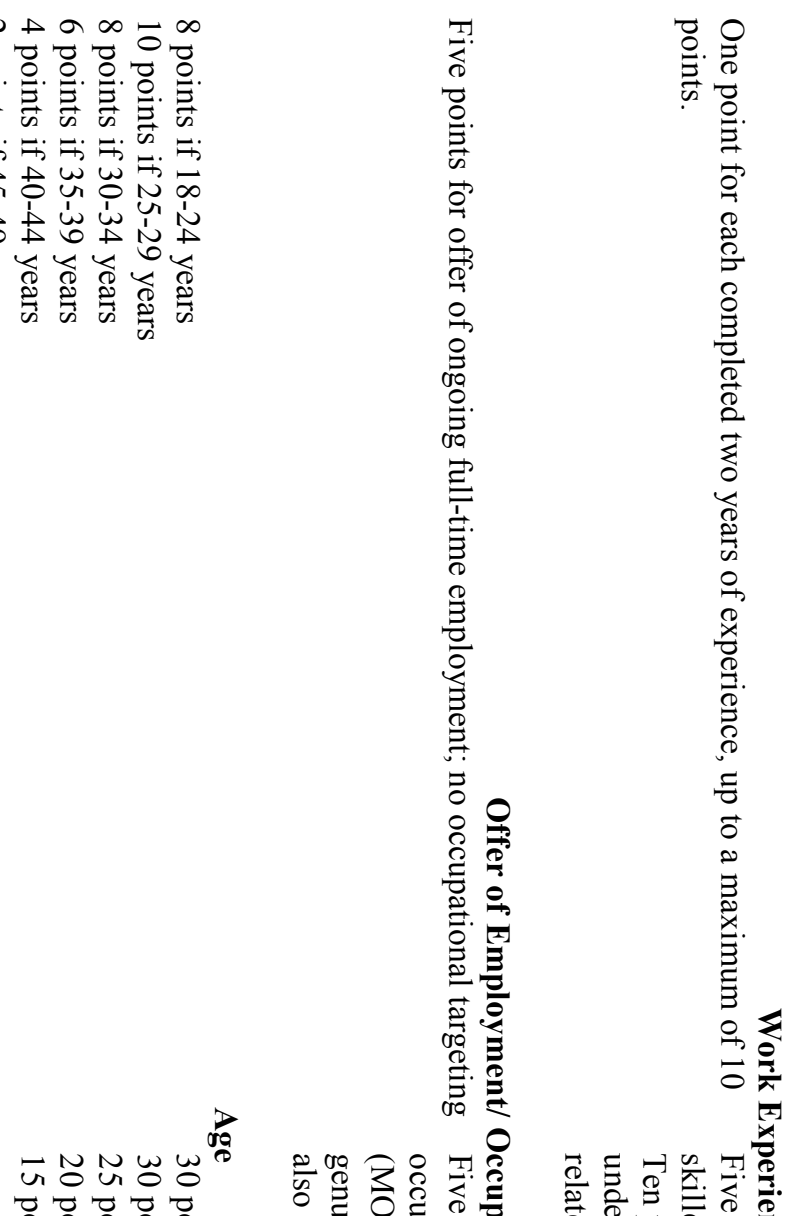

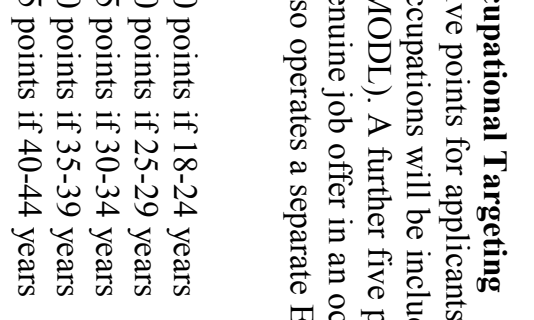

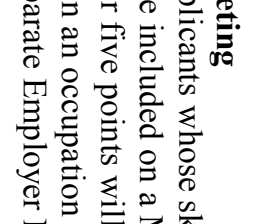

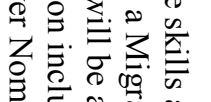

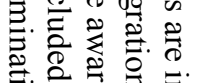

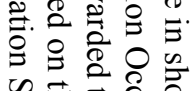

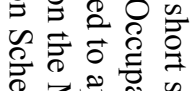

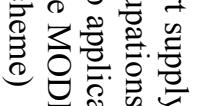

党空

Z记萧

俤萬

0
0
0

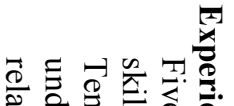

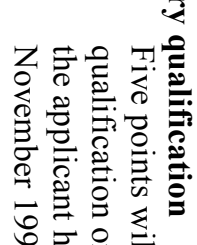

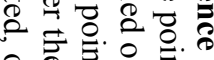

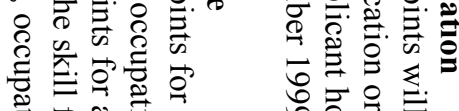

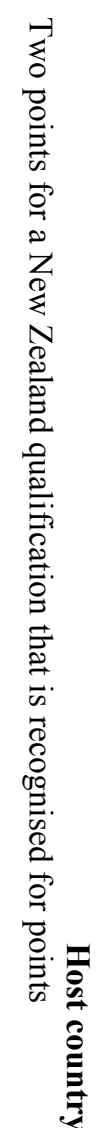

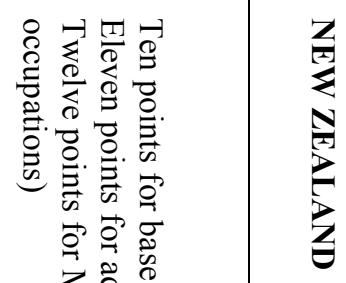

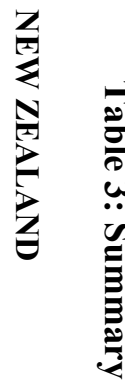

ब.

के क्ष

वे.

용

름.

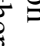

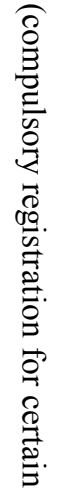

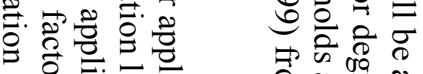

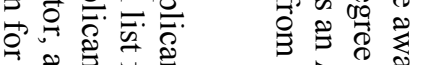

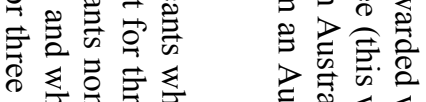

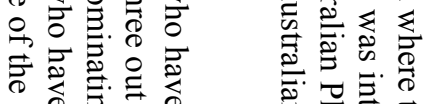

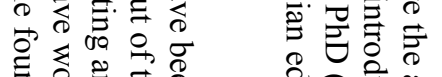

至

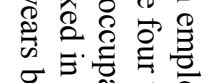

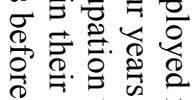

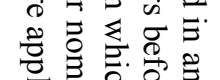

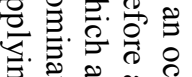

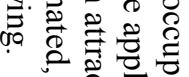

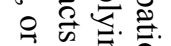

क वें

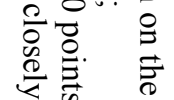

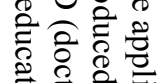

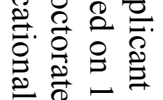

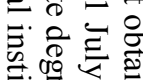

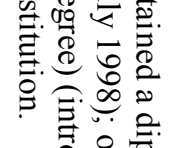

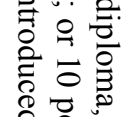

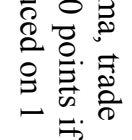

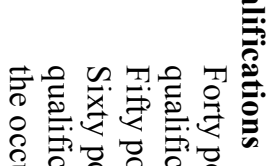

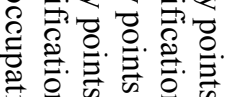

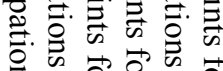

« $\vec{\circ}$ 它

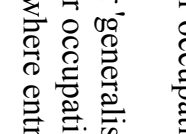

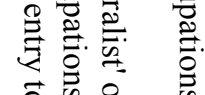

至声席

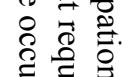

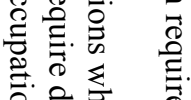

두유.

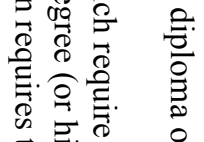

롤. 둥.

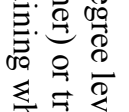

这.

जे 훙 흘

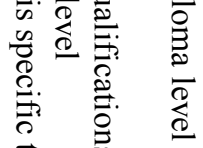

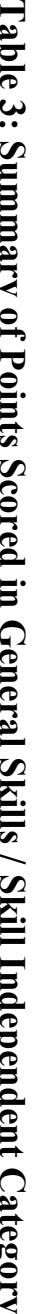




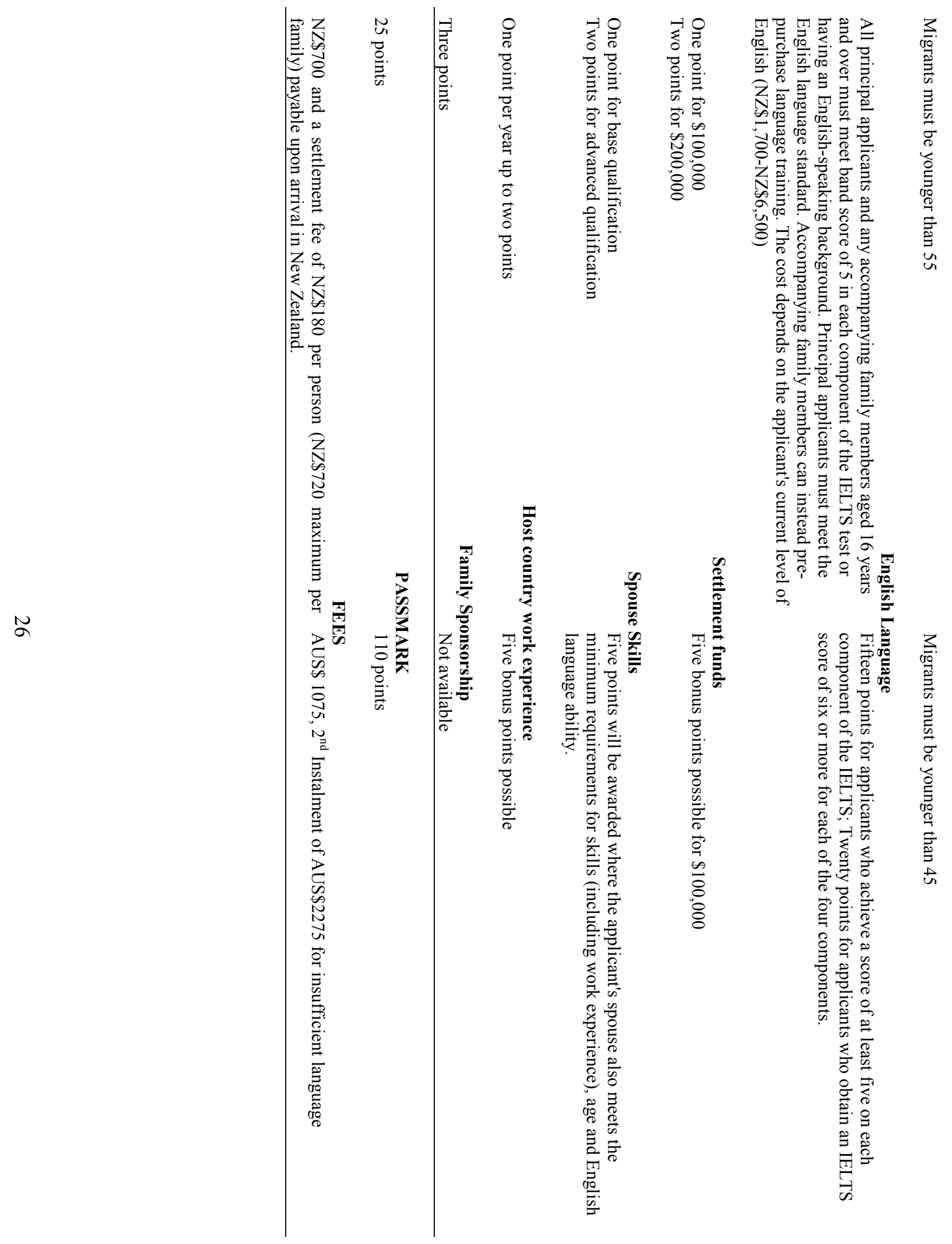




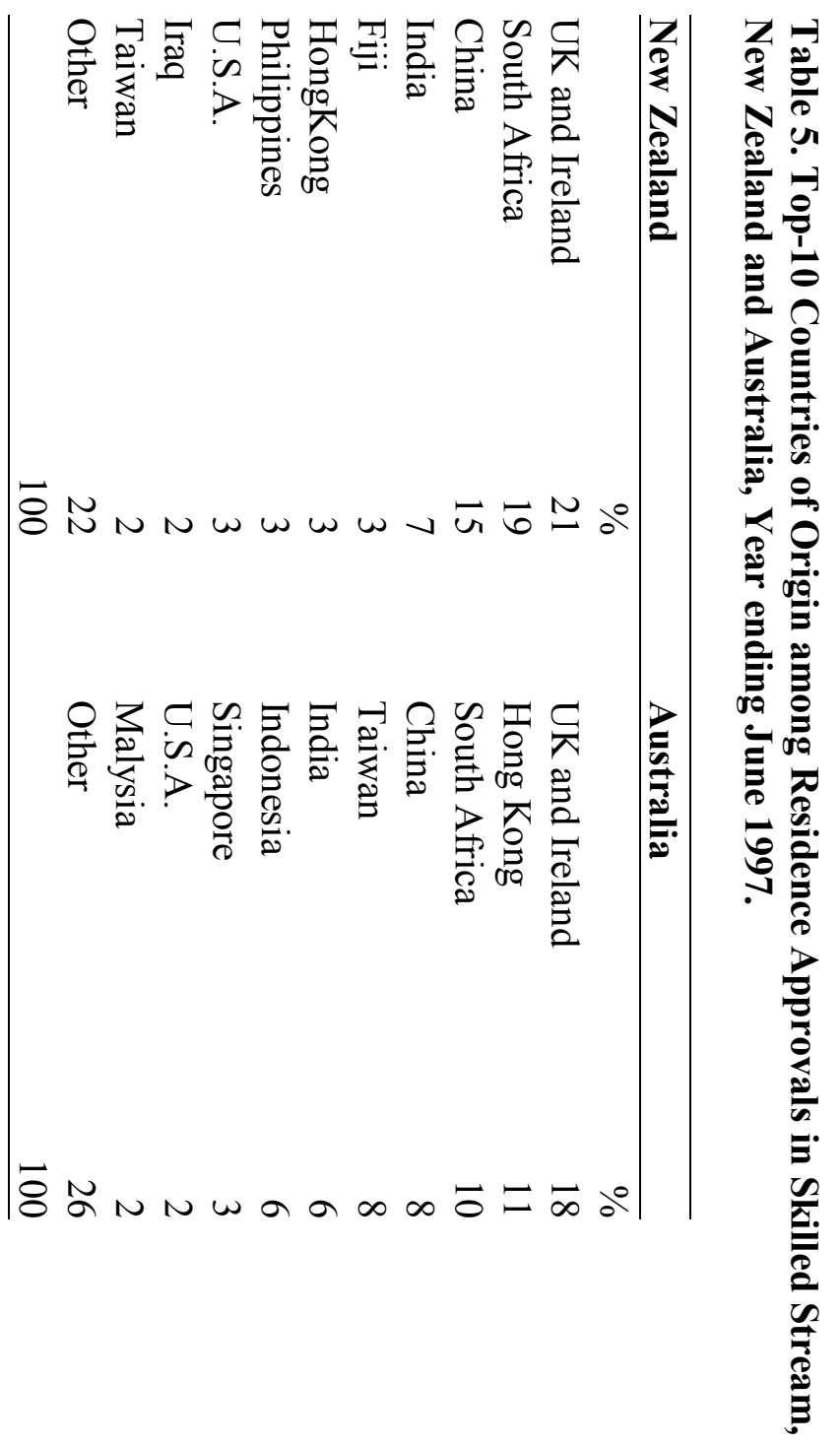




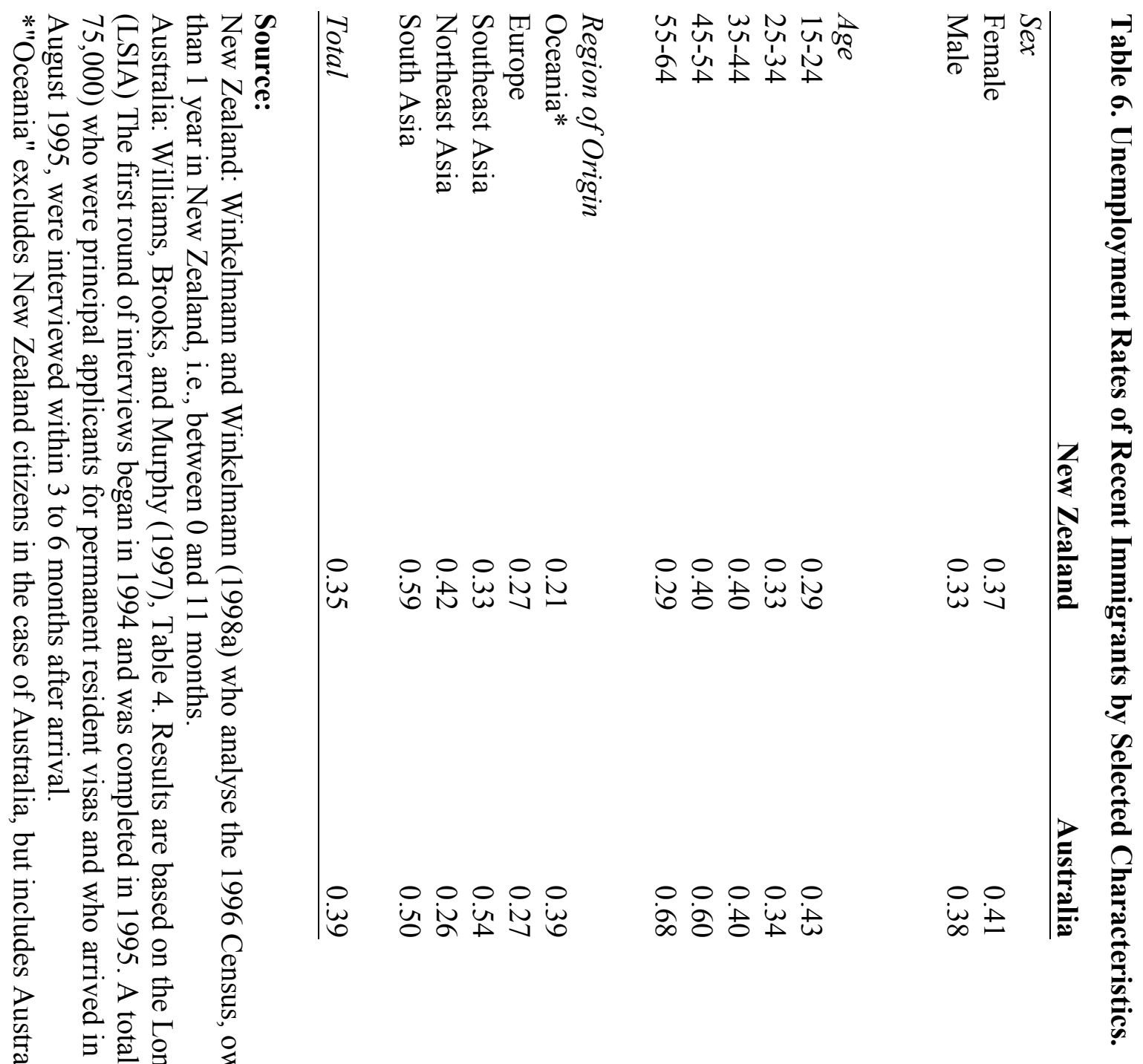




\footnotetext{
${ }^{1}$ Concise summaries of the two countries' earlier migration experiences can be found in Price (1998), Burke (1986), and Shroff (1988).

${ }^{2}$ Australia has about 6 inhabitants per square mile and New Zealand about 33. This is well below the United States (74), or Western European countries such as Germany (600). (Statistical Abstracts of the United States, 1994).

${ }^{3}$ As a matter of fact, the net migration rate had turned negative again by the end of the decade. For the year ending January 2000 there was a net loss of 9,460 permanent and long-term migrants, up 14 per cent on the net outflow of 8,330 in the January 1999 year (Statistics New Zealand, External Migration (January 2000) - Media Release).

${ }^{4}$ The economic determinants of Trans-Tasman migration have been studied in Brosnan and Poot (1987), Gorbey, James and Poot (1999), Poot (1995), Poot, Nana and Philpott (1988), and Nana and Poot (1996), among others.

${ }^{5}$ Of the 24,686 New Zealand permanent migrants to Australia in 1998/99, only 76 percent were born in New

Zealand. The rest were "step-migrants" (DIMA, 2000). New Zealand permanent residents can apply for citizenship after 3 years of residence (Citizenship can be obtained after 2 years of residence in Australia).

${ }^{6}$ On 30 June 1997, a further 19.2 per cent were Australia-born but had at least one parent born overseas.

${ }^{7}$ These tabulations are made available by the respective immigration services over the internet. In fact, it is possible for prospective immigrants anywhere in the world to conduct a self-assessment and to find out whether or not the combined number of points is sufficient for immigration. The transparency of the system is somewhat diminished in Australia, since the various occupational classifications require judgements that may not be immediately available to the individual.

${ }^{8}$ People with outstanding academic or other abilities can apply under different programs, such as the "Distinguished Talent Scheme", or the "Employer Nomination Scheme".

${ }^{9}$ Literally speaking, not everyone coming through the economic category is points tested, since the points test only involves the principal applicant, although accompanying direct family members are also counted among immigrants in that class.

${ }^{10}$ It was mentioned before, that New Zealand was the most important country of origin for Australian immigrants in the late 1990s. However, since New Zealanders do not need residence approval, they are not included in this table.
} 


\section{IZA Discussion Papers}

No. Author(s)

71

72

L. Goerke

J. Fersterer

R. Winter-Ebmer

73

G. S. Epstein

S. Nitzan

74 M. Kräkel

75

B. Henry

M. Karanassou

D. J. Snower

76

G. Brunello

M. Giannini

77

C. M. Schmidt

78

J. Hansen

R. Wahlberg

79

J. S. Earle

Z. Sakova

80 J. C. van Ours

J. Veenman

81

T. J. Hatton

S. Wheatley Price

82 K. A. Konrad

83

R. Euwals

84

C. M. Schmidt

85 S. Pudney

M. A. Shields

86

J.P. Haisken-DeNew

C. M. Schmidt

87
Title

Area

Date

The Wedge

3

$11 / 99$

Are Austrian Returns to Education Falling Over

Time?

The Endogenous Determination of Minimum Wage 3

Strategic Mismatches in Competing Teams

5

Adjustment Dynamics and the Natural Rate: An 1

Account of UK Unemployment

Selective Schools

5

Knowing What Works: The Case for Rigorous

Program Evaluation

Endogenous Schooling and the Distribution of the Gender Wage Gap

Entrepreneurship from Scratch: Lessons on the Entry Decision into Self-Employment from Transition Economies

The Netherlands: Old Emigrants - Young Immigrant Country

Migration, Migrants and Policy in the United Kingdom

Privacy, time consistent optimal labor income taxation and education policy

Female Labour Supply, Flexibility of Working Hours, 1 and Job Mobility in the Netherlands

The Heterogeneity and Cyclical Sensitivity of 1 Unemployment: An Exploration of German Labor Market Flows

Gender and Racial Discrimination in Pay and 5/6 Promotion for NHS Nurses

Money for Nothing and Your Chips for Free?

5 The Anatomy of the PC Wage Differential

Educational Mismatch and Wages in Germany
5

$11 / 99$

$11 / 99$

$12 / 99$

$12 / 99$

$12 / 99$

$12 / 99$

$12 / 99$

$12 / 99$

$12 / 99$

$12 / 99$

$12 / 99$

$12 / 99$

12/99

$12 / 99$

$12 / 99$

$12 / 99$ 
P. Cahuc

A. Zylberberg

97

A. Barrett

98

J.P. Haisken-DeNew

C. M. Schmidt

L. Husted

H. S. Nielsen

M. Rosholm

N. Smith
G. Brunello
C. Graziano
B. Parigi

Migration in Spain: Historical Background and 1 Current Trends

Aliyah to Israel: Immigration under Conditions of 1 Adversity

Tenures that Shook the World: Worker Turnover in $\quad 4$ Russia, Poland and Britain

Identification and Estimation of Causal Effects of 6 Multiple Treatments Under the Conditional Independence Assumption

The Rate of Return to Private Schooling

An Evaluation of Public-Sector-Sponsored

\section{Germany}

An Evaluation of Public Employment Programmes 6 in the East German State of Sachsen-Anhalt

Job Protection, Minimum Wage and Unemployment 3

Irish Migration: Characteristics, Causes and 1

Industry Wage Differentials Revisited: A

Longitudinal Comparison of Germany and USA

Residential Location and Youth Unemployment: 1

The Economic Geography of School-to-Work-

Transitions

Immigrant Assimilation and Welfare Participation: 1/3

Do Immigrants Assimilate Into or Out-of Welfare?

Employment and Wage Assimilation of Male First 3 Generation Immigrants in Denmark

Labor Supply and Matching Rates for Welfare

Characteristics

Estimation in a Duration Model for Evaluating

Matching Model with Uncertainty -

An Extension of Mortensen and Pissarides (1994)

Ownership or Performance: What Determines 1 
1979 - 1990: An analysis of the (West-)German multivariate failure times and unobserved heterogeneity

107 J. C. van Ours G. Ridder

J. Boone

J. C. van Ours

G. J. van den Berg

B. van der Klaauw

110 D. DeVoretz

C. Werner

111 V. Sorm

K. Terrell

L. Bellmann

T. Schank

113 R. Euwals

114 G. Brunello

A. Medio

115 A. Cigno

F. C. Rosati

116 C. Belzil

117 S. Bender

A. Haas

C. Klose

118 M. A. Shields

M. E. Ward

119 A. Lindbeck

D. J. Snower

120 P. T. Pereira

P. S. Martins

121 J. C. van Ours

122 D. Munich

J. Svejnar

K. Terrell

123 J. Hunt
Fast Track or Failure: A Study of the Completion

Rates of Graduate Students in Economics

Modeling Financial Incentives to Get Unemployed Back to Work

Combining Micro and Macro Unemployment

Duration Data

A Theory of Social Forces and Immigrant Second

Language Acquisition

Sectoral Restructuring and Labor Mobility:

A Comparative Look at the Czech Republic

Innovations, Wages and Demand for

Heterogeneous Labour: New Evidence from a

Matched Employer-Employee Data-Set

Do Mandatory Pensions Decrease Household

Savings? Evidence for the Netherlands

An Explanation of International Differences in

Education and Workplace Training

Why do Indian Children Work, and is it Bad for

Them?

Unemployment Insurance and Subsequent Job

Duration: Job Matching vs. Unobserved

Heterogeneity

IAB Employment Subsample 1975-1995.

Opportunities for Analysis Provided by the

Anonymised Subsample

Improving Nurse Retention in the British National

Health Service: The Impact of Job Satisfaction on

Intentions to Quit

The Division of Labor and the Market for

Organizations

Does Education Reduce Wage Inequality?

Quantile Regressions Evidence from Fifteen

European Countries

Do Active Labor Market Policies Help Unemployed Workers to Find and Keep Regular Jobs?

Returns to Human Capital under the Communist

Wage Grid and During the Transition to a Market

Economy

Why Do People Still Live in East Germany?
3

5

$2 / 00$

5

$2 / 00$

5

$2 / 00$

$1 / 00$

$1 / 00$

$1 / 00$

$2 / 00$

$2 / 00$

$2 / 00$

$2 / 00$

$2 / 00$

$2 / 00$

$2 / 00$

$2 / 00$

7

/00

$3 / 00$

$4 / 6$

4

$3 / 00$ 
Rational Poverty or Poor Rationality? The Take-up

125 F. Büchel

J. R. Frick

of Social Assistance Benefits

The Income Portfolio of Immigrants in Germany - $\quad 1 / 3$

$3 / 00$

Effects of Ethnic Origin and Assimilation. Or:

Who Gains from Income Re-Distribution?

126 J. Fersterer

R. Winter-Ebmer

Smoking, Discount Rates, and Returns to

Education

127 M. Karanassou

D. J. Snower

Characteristics of Unemployment Dynamics: The

Chain Reaction Approach

128 O. Ashenfelter

Do Unemployment Insurance Recipients Actively

Seek Work? Evidence From Randomized Trials in

D. Ashmore

O. Deschênes

129 B. R. Chiswick

M. E. Hurst

130 G. Brunello

S. Comi

C. Lucifora

Four U.S. States

The Employment, Unemployment and

Unemployment Compensation Benefits of

$1 / 3 \quad 3 / 00$

Immigrants

The Returns to Education in Italy: A New Look at $5 \quad 3 / 00$

the Evidence

Are Immigrants Favorably Self-Selected? An $\quad 1 \quad 3 / 00$

Economic Analysis

Hours and Wages in the Depression: British $7 \quad 3 / 00$

Engineering, 1926-1938

Paid and Unpaid Overtime Working in Germany and $1 \quad 3 / 00$

133 D. N. F. Bell

R. A. Hart

O. Hübler

W. Schwerdt

134 A. D. Kugler

G. Saint-Paul

135 A. Barrett

P. J. O'Connell

the UK

Hiring and Firing Costs, Adverse Selection and

3

$3 / 00$

Long-term Unemployment

Is There a Wage Premium for Returning Irish

1

$3 / 00$

Migrants?

136 M. Bräuninger

M. Pannenberg

Unemployment and Productivity Growth: An

3

$3 / 00$

Empirical Analysis within the Augmented Solow

Model

137 J.-St. Pischke

Continuous Training in Germany

$3 / 00$

138 J. Zweimüller

R. Winter-Ebmer

Firm-specific Training: Consequences for Job

Mobility

139 R. A. Hart

Y. Ma

Wages, Hours and Human Capital over the

Life Cycle

5

$3 / 00$

Education and Earnings Growth: Evidence from 11

European Countries

The Effects of Public Sector Sponsored Training on

Individual Employment Performance in East

$4 / 00$ 

both Worlds?

$\begin{array}{cl}145 & \text { M.-S. Yun } \\ 146 & \begin{array}{l}\text { T. K. Bauer } \\ \text { J.P. Haisken-DeNew }\end{array} \\ 147 & \begin{array}{l}\text { M. Belot } \\ \text { J. C. van Ours }\end{array}\end{array}$

Decomposition Analysis for a Binary Choice Model

Does the Recent Success of Some OECD

Microeconometric Evaluation of the Active Labour 6 Market Policy in Switzerland

The Duration of Immigrants' Unemployment Spells: $\quad 1 / 3 \quad 5 / 00$

155 J. Hansen

156 C. Dustmann Evidence from Sweden

Language Proficiency and Labour Market Per- 1

M. Jäntti

O. Raaum

E. Österbacka

Finland, Norway and Sweden Compared to the United States 

Models: The Case of the Self-Employed and the Increase in the Schooling Premium in the 1980's

161 V. Gimpelson

Public Employment and Redistributive Politics:

4

D. Treisman

Evidence from Russia's Regions

G. Monusova

162 C. Dustmann

M. E. Rochina-

Selection Correction in Panel Data Models: An

6

$6 / 00$

Barrachina

Application to Labour Supply and Wages

163 R. A. Hart

Y. Ma

Why do Firms Pay an Overtime Premium?

5

$6 / 00$

164 M. A. Shields

Racial Harassment, Job Satisfaction and Intentions

5

$6 / 00$

S. Wheatley Price

to Quit: Evidence from the British Nursing Profession

165

P. J. Pedersen

Immigration in a High Unemployment Economy: 1

166 Z. MacDonald The Recent Danish Experience

M. A. Shields

The Impact of Alcohol Consumption on Occupa- 5 tional Attainment in England

167 A. Barrett

J. FitzGerald

Earnings Inequality, Returns to Immigration into Ireland

B. Nolan

168 G. S. Epstein

A. L. Hillman

Social Harmony at the Boundaries of the Welfare 3

R. Winkelmann

State: Immigrants and Social Transfers 